DOI 10.22460/jpmi.v1i3.383-394

\title{
ANALISIS KEMAMPUAN BERPIKIR KREATIF MATEMATIS SISWA SMA KELAS XI PADA MATERI TRIGONOMETRI DITINJAU DARI SELF CONFIDENCE
}

\author{
Iis Trisnawati ${ }^{1}$, Wulan Pratiwi $^{2}$, Puji Nurfauziah $^{3}$, Rippi Maya $^{4}$ \\ 1,2,3,4 IKIP Siliwangi, Jl. Terusan Jenderal Sudirman, Cimahi, Jawa Barat, Indonesia \\ ${ }^{1}$ trisnaiis15@gmail.com, ${ }^{2}$ wulanhartono10@ gmail.com
}

Diterima: 17 April 2018; Disetujui: 28 Mei 2018

\begin{abstract}
The purpose of this study is to analyze mathematic creatively thinking and analyze students' difficulties in solving the problem of mathematical creative thinking on Trigonometric material in review of self confidence. The subjects of this study were students of class XI MAN Kota Cimahi that consists of 27 students. The method used in this research is descriptive method with qualitative approach. The stage of this research consists of five stages, including: filling self confidence, tests of mathematical creative thinking ability, interviews, analysze and take a conclusions. The results of the research showed that, when that self confidence affect the improvement of mathematical creative thinking in students. The higher self confidence in the students, the curiosity of students will be encouraged and will increase the ability of creative thinking mathematics. Otherwise, if the self confidence in students is lower, than the student's curiosity is less encouraged and this will have an impact to increase the ability to think creative mathematics.
\end{abstract}

Keywords: Mathematical Creative Thinking, Self Confidence, Trigonometry

\begin{abstract}
Abstrak
Tujuan penelitian ini untuk menganalisis kemampuan berpikir kreatif matematik dan kesulitan siswa dalam menyelesaikan soal kemampuan berpikir kreatif matematik pada materi Trigonometri di tinjau dari self confidence. Subyek penelitian ini adalah siswa kelas XI MAN di kota Cimahi, sebanyak 27 siswa. Metode yang digunakan pada penelitian ini yaitu metode deskriptif dengan pendekatan kualitatif. Adapun tahap penelitian yang dilakukan terdiri dari 5 tahap, antara lain: pengisian skala self confidence, tes kemampuan berpikir kreatif matematik, wawancara, analisis data dan menarik kesimpulan. Berdasarkan hasil penelitian diperoleh bahwa, self confidence berpengaruh kepada peningkatan berpikir kreatif matematik pada siswa. Semakin tinggi self confidence pada siswa, maka rasa ingin tahu siswa akan terdorong dan akan meningkatnya kemampuan berpikir kreatif matematik. Begitupun sebaliknya, semakin rendah self confidence pada siswa, maka rasa ingin tahu siswa kurang terdorong dan ini akan berdampak kepada peningkatan kemampuan berpikir kreatif matematik.
\end{abstract}

Kata Kunci: Berpikir Kreatif Matematik, Self Confidence, Trigonometri

How to cite: Trisnawati, I., Pratiwi, W., Nurfauziah, P., \& Maya, R. (2018). Analisis Kemampuan Berpikir Kreatif Matematis Siswa SMA Kelas XI pada Materi Trigonometri ditinjau dari Self Confidence. JPMI - Jurnal Pembelajaran Matematika Inovatif, 1 (3), 383394. 


\section{PENDAHULUAN}

Berpikir kreatif atau kreativitas sendiri masih menjadi isu yang menarik di kalangan peneliti. Mendesain pembelajaran yang dapat memberikan siswa kesempatan yang lebih untuk mengeksplorasi permasalahan yang memberikan banyak solusi dapat meningkatkan kemampuan siswa dalam bepikir kreatif (Fardah 2012). Berpikir kreatif diperlukan bagi seseorang karena ini adalah dasar untuk menanggapi respon yang diterima dalam mencari solusi atas permasalahan yang dihadapinya. Mengingat permasalahan yang dihadapi belum tentu dapat diselesaikan dengan cara yang telah ada sebelumnya, tetapi membutuhkan kombinasi baru baik itu dalam bentuk sikap, ide maupun produk pikiran agar masalah dapat terselesaikan (Fitriarosah 2016)

Hingga saat ini, fakta di lapangan menunjukkan bahwa kemampuan berpikir kreatif matematis siswa belum berkembang dengan baik pada semua aspek. Salah satunya adalah penelitian yang dilakukan oleh (Purnomo, D.J., Asikin, M., Junaedi 2015) yang hasil studinya menyatakan bahwa tingkat berpikir kreatif siswa cenderung rendah, tidak berpikir mendalam (berpikir cepat), memiliki tingkat ingin tahu yang biasa saja untuk menyelesaikan masalah berpikir kreatif sehingga mereka memberikan jawaban yang sederhana sesuai dengan permintaan soal. Lemahnya kemampuan berpikir kreatif matematis siswa dapat disebabkan oleh beberapa faktor (Martyanti 2013). Salah satunya seperti yang oleh Johnson (Happy dan Widjajanti, 2014) bahwa jika siswa diberi kesempatan untuk melatih kemampuan berpikirnya, nantinya akan terbentuk suatu kebiasaan untuk dapat membedakan antara benar dan tidak benar, dugaan dan kenyataan, fakta dan opini, serta pengetahuan dan keyakinan. Faktor yang mempengaruhi lemahnya kemampuan berpikir kreatif matematis siswa disebabkan kurangnya melatih atau mengeksplor kemampuan berpikir pada siswa (Dilla, Hidayat, \& Rohaeti, 2018; Hidayat, 2011; 2012; Sumarmo, Hidayat, Zukarnaen, Hamidah, \& Sariningsih, 2012; Sumarmo, Mulyani, \& Hidayat, 2018; Tresnawati, Hidayat, \& Rohaeti, 2017).

Isaksen dan Treffinger (Fitriarosah 2016) mendefinisikan berpikir kreatif sebagai proses konstruksi ide yang menekankan pada aspek kelancaran, keluwesan, kebaruan, dan keterincian. Kelancaran dapat diidentifikasi dari banyaknya respon siswa yang relevan(Fitriarosah 2016). Dari respon-respon siswa tersebut masih dapat dikategorikan menjadi beberapa kategori yang mana hal ini terkait dengan aspek keluwesan. Ada kemungkinan respon yang diberikan siswa banyak tetapi hanya merupakan satu kagetori. Respon siswa tersebut dikatakan asli (kebaharuan) jika unik, tidak biasa, dan hanya dilakukan oleh sedikit sekali siswa. Respon tersebut dikatakan rinci jika prosedurnya runtut, logis, jelas, dan beralasan.

Berpikir kreatif matematis berdampak pada kemampuan siswa dalam pengaturan konsep kepercayaan diri atau self confidence mereka. Semua aspek berpikir kreatif matematis, kepercayaan diri siswa lebih dominan dilatih untuk muncul. Suhendri (Martyanti 2013) menyatakan bahwa rasa percaya diri atau self-confidence merupakan suatu sikap mental positif dari seorang individu yang memposisikan atau mengkondisikan dirinya dapat mengevaluasi tentang diri sendiri dan lingkungannya sehingga merasa nyaman untuk melakukan kegiatan dalam upaya mencapai tujuan yang direncanakanPenulis memandang bahwa untuk mengatasi kesulitan dalam meningkatkan kemampuan berpikir kreatif matematis siswa, self confidence memiliki banyak kelebihan jika digunakan sebagai alternatif pembelajaran matematika untuk mengembangkan kemampuan berpikir kreatif siswa. (Hendiana, H. Rohaeti, E. dan Sumarmo 2014) menyatakan bahwa self confidence terdiri atas empat indikator yaitu a) Percaya kepada kemampuan sendiri; b) Bertindak mandiri dalam 
mengambil keputusan; c) Memiliki konsep diri yang positif; d) Berani mengungkapkan pendapat saat berdiskusi; e) Berani menghadapi tantangan.

Penelitian ini bertujuan untuk mengetahui kemampuan berpikir kreatif matematik ditinjau dari self confidende siswa MAN kelas XI di kota Cimahi pada materi Trigonometri berdasarkan aspek kemampuan berpikir kreatif, kelancaran (fluency), keluwesan (flexibility), keaslian (originality), dan keterincian (elaboration) dan aspek, percaya kepada kemampuan sendiri, bertindak mandiri dalam mengambil keputusan, memiliki konsep diri yang positif, berani mengungkapkan pendapat dan berani menghadapi tantangan. Selain itu juga menganalisis kesulitan-kesulitan siswa dalam menyelesaikan soal-soal tes berpikir kreatif.

\section{METODE}

Penelitian ini merupakan penelitian deskriptif dengan pendekatan kualitatif. Subjek dari penelitian yaitu siswa kelas XI MAN Kota Cimahi yang terdiri dari 27 Siswa yang telah menempuh materi Trigonometri. Instrumen dalam penelitian ini adalah non-tes yaitu berupa skala self confidence siswa, soal tes kemampuan berpikir kreatif matematik dan wawancara. Tahapan awal yang dilakukan dalam penelitian ini yaitu dengan menyusun angket self confidence. Dalam hal ini peneliti menggunakan skala dari sumber yang telah ada yaitu dari (Hendiana, H. Rohaeti, E. dan Sumarmo 2014), kemudian peneliti memodifikasi skala tersebut yang terdiri dari 20 (dua puluh) pernyataan, yang setiap pertanyaan dilengkapi empat alternatif jawaban yaitu sangat sering (SS), sering (S), jarang (JR), dan jarang sekali (JS).

Pemberian skor skala sikap untuk setiap pilihan jawaban positif berturut-turut 4, 3, 2, 1 dan sebaliknya 1, 2,3, 4, untuk pernyataan negatif (Ruseffendi n.d.)Akan diperoleh level self confidence siswa tinggi, sedang dan rendah. Teknik analisis data yang digunakan adalah teknik analisis persentase (Maretha, \& Ibrahim, 2014)dengan rumus sebagai berikut.

$$
\mathrm{P}=\frac{f}{n} \times 100
$$

Keterangan:

$\mathrm{P}=$ Presentase

$\mathrm{F}=$ Frekuensi jawaban

$\mathrm{N}=$ Jumlah responden

Selain menggunakan skala, peneliti menguji cobakan instrumen soal berpikir kreatif matematik yang terdiri dari 5 (lima) soal yang sudah di uji validitas, reliabilitas, dan indeks kesukarannya, terdiri dari dua soal aspek berpikir lancar dan masing-masing satu soal untuk aspek berpikir luwes, asli dan keterincian. Untuk menganalisis jawaban tes dilakukan dengan menilai soal tes sesuai dengan rubrik penskoran yang telah disediakan. Untuk mengukur kemampuan berpikir kreatif matematik siswa secara individu;

$$
\mathrm{P}=\frac{x}{y} \times 100
$$

Keterangan:

$\mathrm{P}=$ Tingkat kemampuan berpikir kreatif matematik tiap individu 
$\mathrm{X}=$ Skor total yang diperoleh tiap individu

$\mathrm{Y}=$ Skor maksimum tiap individu

Kemudian dikategorikan dengan menggunakan konversi skor Nurkancana dan Sunarta (Arifani, H. N., Sunardi, dan Setiawani 2015). Setelah itu diolah melalui level self confidence siswa lalu akan diperoleh persentase untuk setiap soalnya. Kemudian diambil sampel jawaban siswa untuk dianalisis letak kesalahan berdasarkan indikator kemampuan berpikir kreatif matematik. Setelah analisis dilakukan tahap selanjutnya yaitu peneliti mengambil kesimpulan dari analisis dan wawancara, wawancara yang dimaksud merupakan tanya jawab seputar kesulitan siswa dalam menyelesaikan soal kemampuan berpikir kreatif matematik dan sefl confidence pada diri siswa selama mengikuti kegiatan belajar mengajar.

\section{HASIL DAN PEMBAHASAN}

\section{Pengkategorian self confidence}

Tabel 1. Kriteria Skala Self Confidence

\begin{tabular}{lccccccc}
\hline & & $\begin{array}{c}\text { Sangat } \\
\text { Tinggi }\end{array}$ & Tinggi & Sedang & Rendah & $\begin{array}{c}\text { Sangat } \\
\text { Rendah }\end{array}$ & Total \\
\hline Kriteria & Rendah & 0 & 0 & 0 & 1 & 14 & 15 \\
Kemampuan & Sedang & 0 & 0 & 0 & 0 & 12 & 12 \\
Berpikir Kreatif & Tinggi & 0 & 0 & 0 & 0 & 0 & 0 \\
\hline Total & & 0 & 0 & 0 & 1 & 26 & 27 \\
\hline
\end{tabular}

Berdasarkan Tabel 1 dapat dilihat bahwa jumlah siswa yang mengikuti tes 27 siswa, setelah skor tes skala diperoleh hasil dengan kategori kepercayaan diri siswa tinggi berjumlah 0 siswa, kategori kepercayaan diri siswa sedang 12 siswa, dan kategori kepercayaan diri siswa rendah berjumlah 15 siswa. Diperoleh bahwa siswa yang memberikan respon terhadap kepercayaan diri siswa terhadap pembelajaran matematika dengan tingkat rata-rata 60\%, dapat diambil kesimpulan bahwa tingkat kepercayaan diri siswa rendah. Karena berdasarkan hasil penelitian maretha, ibrahim dan said (2014) bahwa self confidence yang dikatakan kategori baik adalah ketika lebih dari $60 \%$.

\section{Persentase hasil tes kemampuan berpikir kreatif matematik ditinjau dari self confidence}

Dari hasil tes tertulis terhadap 27 siswa yaitu tentang tingkat kemampuan berpikir kreatif matematik siswa dengan tingkat penjenjangan kemampuan berpikir kreatif menggunakan konversi skor Nurkancana dan Sunarta, diperoleh pada Tabel 1 yang dapat disajikan pada Tabel 2 sebagai berikut.

Tabel 2. Hasil Analisis Kemampuan Berpikir Kreatif Matematis Siswa Tiap Indikator

\begin{tabular}{clcc}
\hline \multirow{2}{*}{ No Soal } & \multicolumn{1}{c}{ Indiaktor } & \multicolumn{2}{c}{ Rata- rata } \\
\cline { 3 - 4 } & & $\begin{array}{c}\text { skala } \\
\mathbf{4}\end{array}$ & $\begin{array}{c}\text { skala } \\
\text { persen }\end{array}$ \\
\hline 1 & Berpikir Lancar (Fluency) & 2 & $39 \%$ \\
2 & Berpikir Lancar (Fluency) & 1 & $23 \%$ \\
3 & Berpikir Keaslian (Originality) & 1 & $15 \%$ \\
4 & Berpikir Luwes (Flexibility) & 2 & $40 \%$ \\
\hline
\end{tabular}




\begin{tabular}{cccc}
\hline \multirow{2}{*}{ No Soal } & Indiaktor & \multicolumn{2}{c}{ Rata- rata } \\
\cline { 3 - 4 } & & skala & skala \\
& & $\mathbf{4}$ & persen \\
\hline 5 & Berpikir keterincian (Elaboration) & 1 & $31 \%$ \\
\hline
\end{tabular}

Dari Tabel 2 diatas dapat dilihat bahwa tidak ada siswa yang memiliki tingkat kemamampuan berpikir kreatif dengan kategori tinggi. Indikator berpikir luwes (Flexibility) dikategorikan cukup baik dan berpikir keaslian (Originality) berada pada kategori yang paling rendah.

\section{Tes berpikir kreatif matematik}

\section{Soal No. 1}

Bimo berada di atas puncak Bukit Bintang dengan ketinggian 300m, karena akan bermain flying fox. Dia melihat Bukit Indah di sebelah utara dengan sudut depresi $30^{\circ}$ dan ketinggian $270 \mathrm{~m}$. Rencananya Bimo akan mendarat tepat di puncak Bukit Indah tersebut.

Buatlah sketsa dari informasi di atas

Buatlah soal dan jawaban dari informasi diatas

Dari 27 siswa terdapat 39\% siswa yang cukup kreatif dalam menyelesaikan permasalahan pada nomer 1. Adapun sampel hasil jawaban siswa pada tingkat kemampuan berpikir kreatif matematik yang cukup kreatif dan sangat kurang:

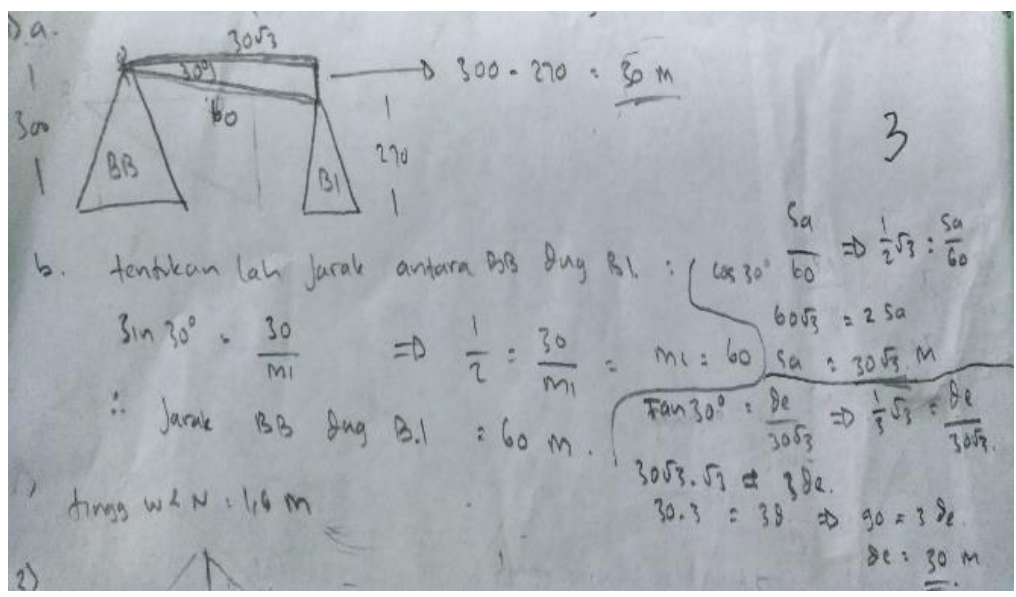

Gambar 1. Analisis kemampuan berpikir kreatif matematik

Dimana siswa mampu memberikan satu cara secara fasih dan satu cara yang belum diselesaikan dengan penyelesaian yang baru atau tidak umum. Namun, terlihat kesalahan yang dilakukan adalah tidak menuliskan unsur-unsur yang diketahui, siswa hanya memberikan sketsa gambar yang lengkap, membuat satu masalah dan tidak menyelesaikan cara lain untuk mengecek jawabannya. Berdasarkan hasil wawancara siswa menyatakan bahwa dalam penyelesaian masalah, siswa mencoba lebih teliti dalam membuat sketsa gambar yang diminta pada soal, yaitu dalam membedakan sudut elevansi dan depresi, dan mencoba untuk 
mengembangkan cara penyelesaian yang pernah diberikan guru, siswa tersebut terlalu terfokus pada nomor 3, sehingga beralasan waktunya habis.

Namun, 3 dari 27 siswa tidak mampu memberikan alternatif penyelesaian masalah baik secara baru, berbeda dan beragam. Siswa tersebut memiliki self confidence rendah dan tingkat kemampuan berpikir kreatif yang sangat kurang, berikut sempel hasil jawaban siswa:

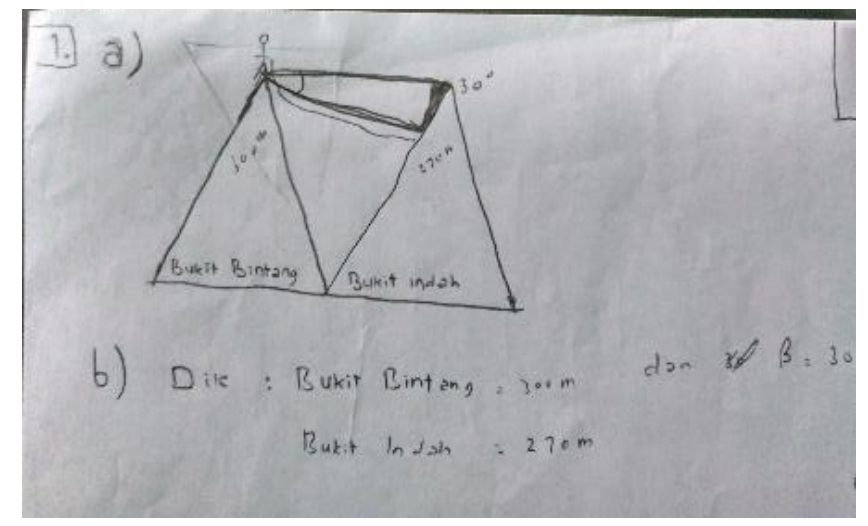

Gambar 2. Analisis kemampuan berpikir kreatif matematik

Berdasarkan hasil wawancara pada siswa yang tingkat kemampuan berpikir kreatif berada pada kategori sangat kurang ini menyatakan bahwa tidak tahu bagaimana menganalisis soal cerita kepada gambar, lupa dengan istilah sudut depresi sehingga siswa tidak percaya diri dalam melanjutkan jawabnnya seperti yang terlihat pada Gambar 2.

\section{Soal No. 2}

Wiki memiliki tinggi badan yang sama dengan Nizam yaitu $160 \mathrm{~cm}$. Wiki dan Nizam sedang mengamati sebuah menara. Wiki berdiri tepat $15 \mathrm{~m}$ dari menara dan melihat puncak menara tersebut membentuk sudut elevansi $45^{\circ}$. Pada arah yang berlawanan Nizam melakukan hal yang sama dengan berdiri di atas loteng rumahnya dengan ketinggian $10 \mathrm{~m}$ dengan jarak menara dan rumahnya $5 \mathrm{~m}$. Dari data diatas, jelaskan dengan menggunakan aljabar, bagaimana cara untuk mencari tinggi menara dan sudut elevansi yang terbentuk saat Nizam melihat menara!

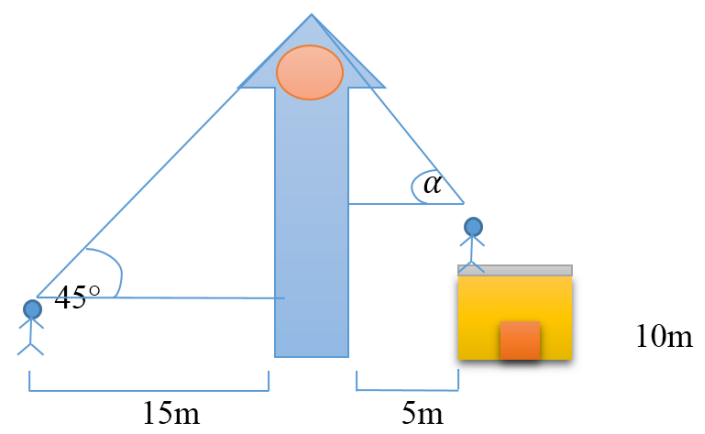

Dari 27 siswa terdapat $23 \%$ siswa yang cukup kreatif dalam menyelesaikan permasalahan pada nomer 2. Adapun sampel hasil jawaban siswa pada tingkat kemampuan berpikir kreatif matematik yang cukup kreatif: 


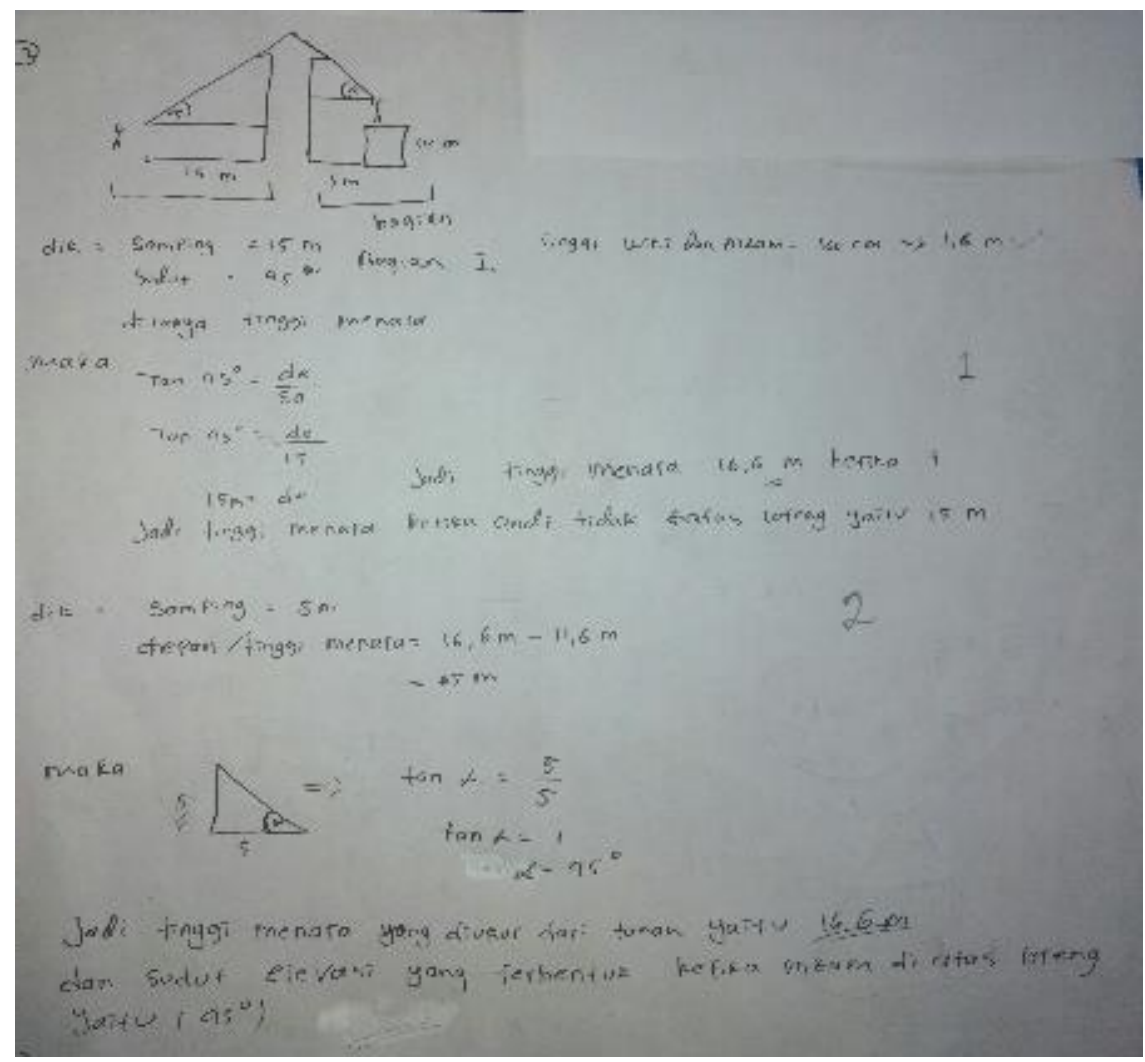

Gambar 3. Analisis kemampuan berpikir kreatif matematik

Siswa mampu memberikan satu cara secara fasih dengan sistematis. Terlihat yang dilakukan siswa adalah menuliskan unsur-unsur yang diketahui, kemudian menyelesaikan soal dengan menganalisis yang harus dikerjakan terlebih dahulu oleh siswa. Namun, siswa tersebut hanya membuat satu penyelesaian, sehingga hanya memberikan jawaban yang sederhana sesuai dengan permintaan soal. Berdasarkan hasil wawancara siswa menyatakan bahwa dalam penyelesaian masalah, siswa mencoba merinci langkah-langkah penyelesaian, yaitu dengan mencari tinggi menara tersebut dengan menggunakan konsep perbandingan segitiga siku-siku.

Namun, 9 dari 27 siswa tidak mampu memberikan alternatif penyelesaian masalah baik secara baru, berbeda dan beragam. Siswa tersebut memiliki self confidence rendah dan tingkat kemampuan berpikir kreatif yang sangat kurang, berikut sempel hasil jawaban siswa:

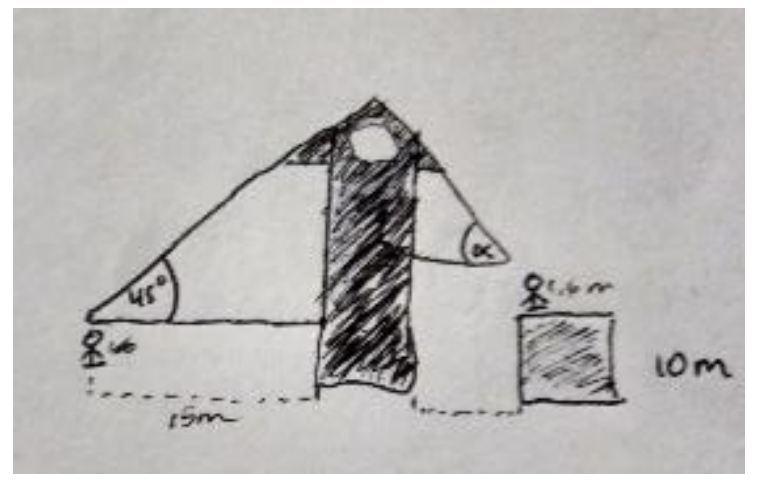

Gambar 4. Analisis kemampuan berpikir kreatif matematik 
Berdasarkan hasil wawancara pada siswa yang tingkat kemampuan berpikir kreatif berada pada kategori sangat kurang ini menyatakan bahwa tidak tahu bagaimana mengerjakan soal tersebut, karena siswa beranggapan soal tersebut tidak bisa diselesaikan karena unsur yang diketahuinya tidak lengkap dan tidak tahu bagaimana mencari unsur-unsur tersebut.

\section{Soal No. 3}

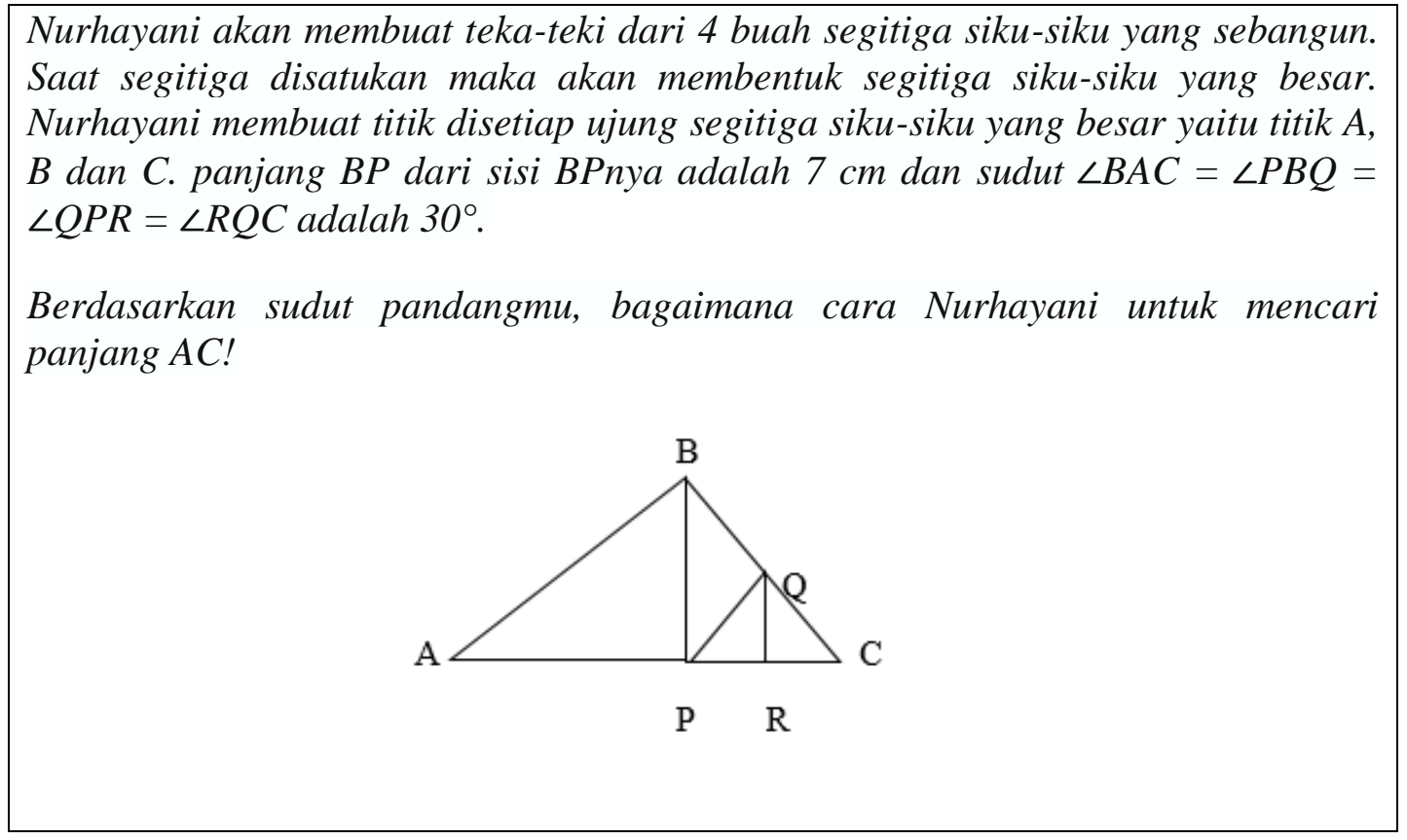

Dari 27 siswa terdapat 15\% siswa yang cukup kreatif dalam menyelesaikan permasalahan pada nomer 4. Adapun sampel hasil jawaban siswa pada tingkat kemampuan berpikir kreatif matematik yang cukup kreatif:
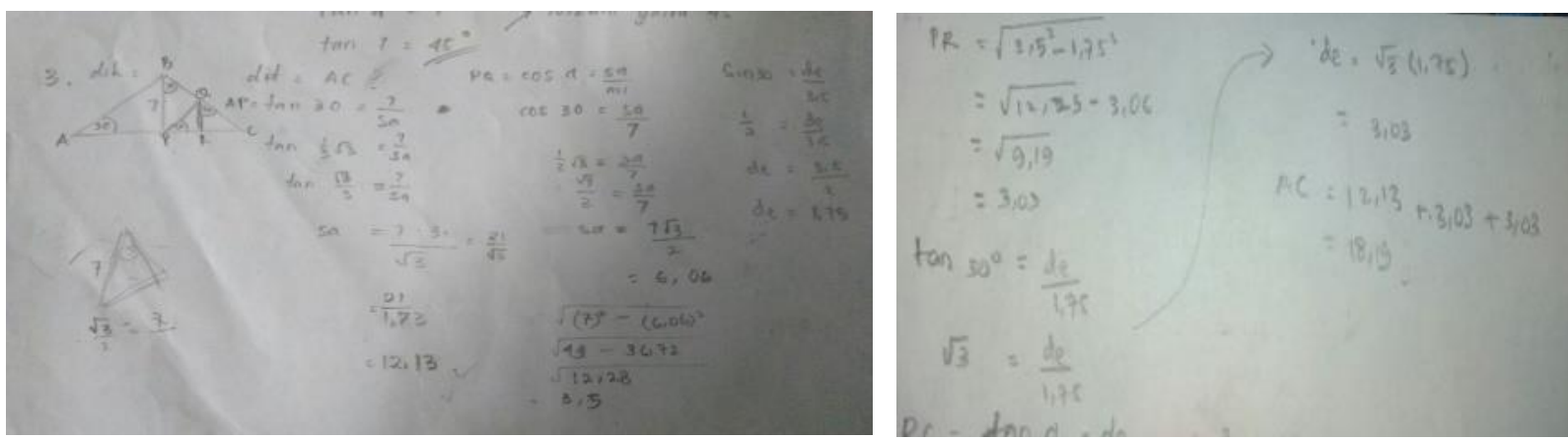

Gambar 5. Analisis kemampuan berpikir kreatif matematik

Siswa tersebut mampu memberikan satu cara secara fasih. Terlihat yang dilakukan siswa adalah menggambarkan kembali dan menuangkan unsur-unsur yang diketahui kepada gambar. Namun, siswa masih belum memberikan jawaban yang lebih memudahkan dalam memilih memakai rumus sinus, cosinus atau tangen. Berdasarkan hasil wawancara siswa menyatakan bahwa dalam penyelesaian masalah, siswa sedikit bingung karena banyak langkah yang harus dikerjakan secara teliti. 
Namun, 12 dari 27 siswa tidak mampu memberikan alternatif penyelesaian masalah baik secara baru, berbeda dan beragam. Siswa tersebut memiliki self confidence rendah dan tingkat kemampuan berpikir kreatif yang sangat kurang. Berdasarkan hasil wawancara pada siswa yang tingkat kemampuan berpikir kreatif berada pada kategori sangat kurang ini menyatakan bahwa untuk mengerjakan nomer 1 dan 2 saja sudah sulit, apalagi dengan mengerjakan nomor 3, sehingga siswa tersebut tidak mencoba untuk menyelesaikan soal tersebut, dan yang dirasakan oleh siswa tersebut adalah pesimis ketika mendapatkan soal yang menurut siswa tersebut sulit.

\section{Soal No. 4}

Perhatikan gambar berikut!

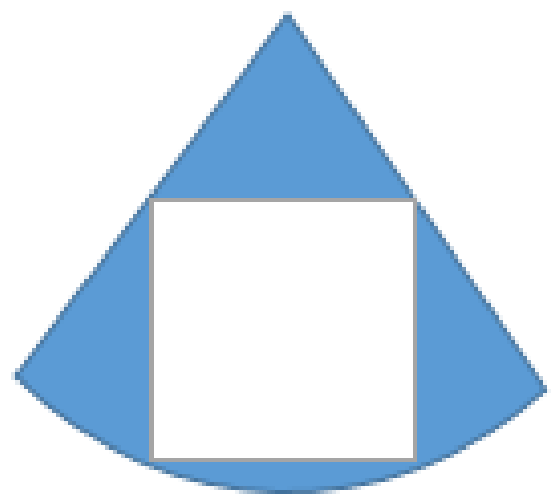

Semua titik sudut suatu persegi dengan panjang sisi s terletak pada batas dari juring lingkaran berjari-jari $15 \mathrm{~cm}$ yang sudut pusatnya $60^{\circ}$. Jika persegi diletakkan secara simetris dalam juring maka berapa nilai $s^{2}$ ? jelaskan pendapatmu!

Dari 27 siswa terdapat 40\% siswa yang cukup kreatif dalam menyelesaikan permasalahan pada nomer 4. Adapun sampel hasil jawaban siswa pada tingkat kemampuan berpikir kreatif matematik yang cukup kreatif: 


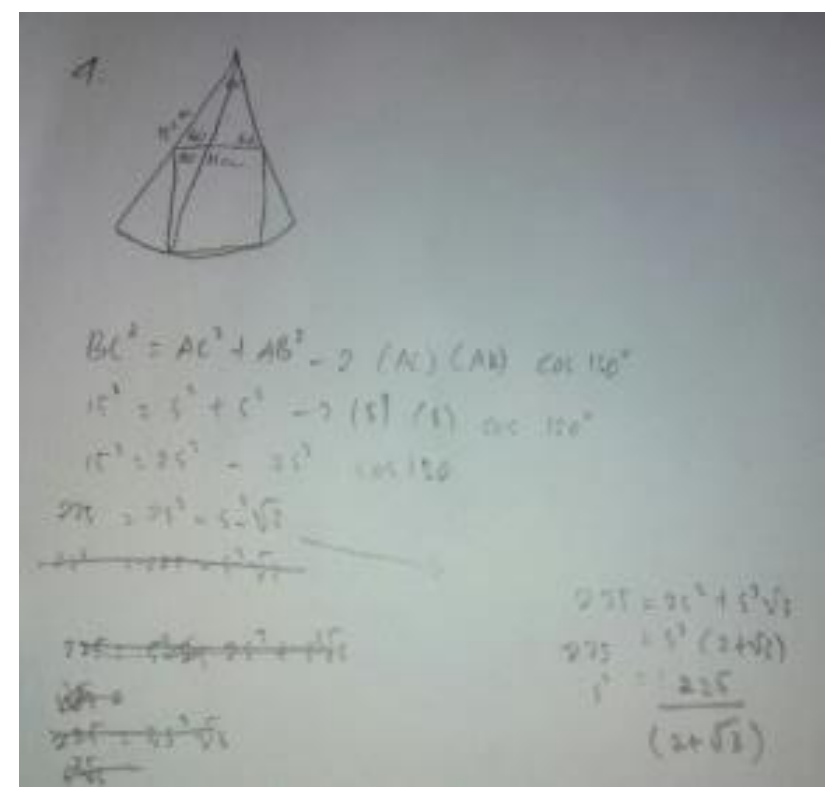

Gambar 6. Analisis kemampuan berpikir kreatif matematik

Siswa tersebut mampu memberikan satu cara secara fasih menggunakan rumus cosinus. Terlihat yang dilakukan siswa adalah menggambarkan kembali dan menuangkan unsur-unsur yang diketahui kepada gambar. Namun, berdasarkan hasil wawancara siswa dalam penyelesaian aljabarnya siswa tersebut masih kebingungan, memang terlihat banyak coretan pada lembar jawaban siswa tersebut.

Namun, 6 dari 27 siswa tidak mampu memberikan alternatif penyelesaian masalah baik secara baru, berbeda dan beragam. Siswa tersebut memiliki self confidence rendah dan tingkat kemampuan berpikir kreatif yang sangat kurang. Berdasarkan hasil wawancara pada siswa yang tingkat kemampuan berpikir kreatif berada pada kategori sangat kurang ini menyatakan bahwa sebenarnya siswa tersebut tidak tahu mana yang dikatakan juring, sehingga siswa tersebut tidak memahami isi soal tersebut.

\section{Soal No. 5}

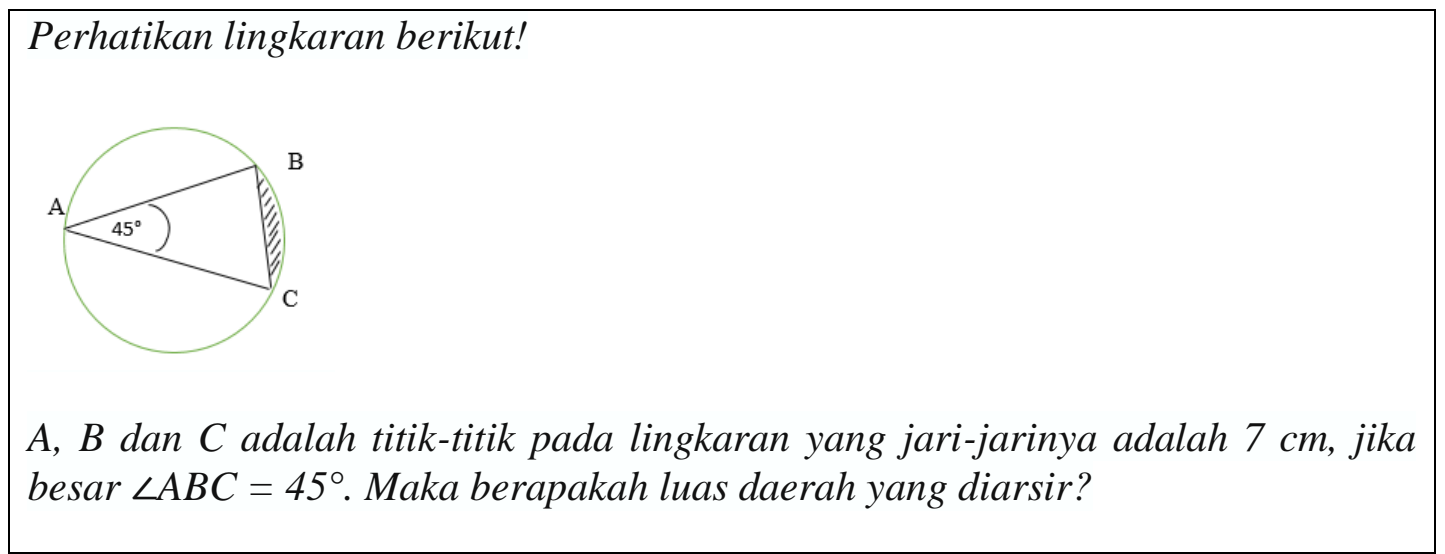

Dari 27 siswa terdapat $31 \%$ siswa yang cukup kreatif dalam menyelesaikan permasalahan pada nomer 4. Adapun sempel hasil jawaban siswa pada tingkat kemampuan berpikir kreatif matematik yang cukup kreatif: 


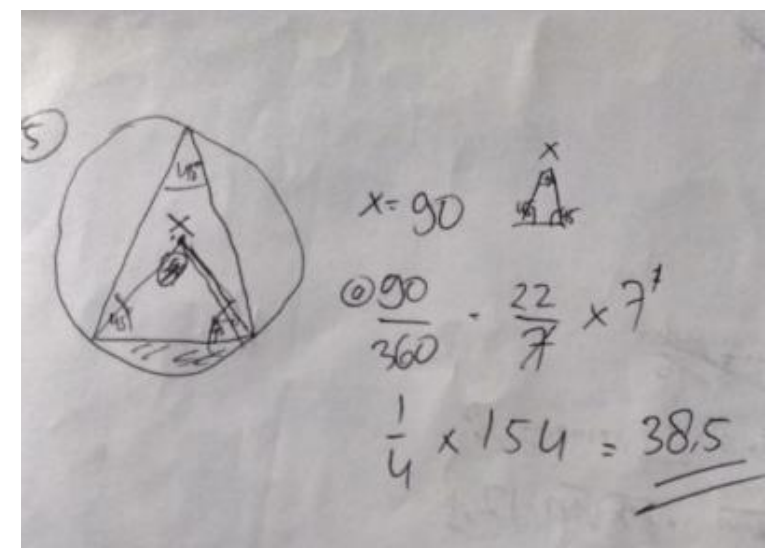

Gambar 7. Analisis kemampuan berpikir kreatif matematik

Siswa tersebut mampu memberikan jawaban namun belum terselesaikan, karena siswa tersebut baru menemukan luas juringnya saja, belum sampai kepada mendapatkan luas segitiganya. Namun, 8 dari 27 siswa tidak mampu memberikan alternatif penyelesaian masalah baik secara baru, berbeda dan beragam. Siswa tersebut memiliki self confidence rendah dan tingkat kemampuan berpikir kreatif yang sangat kurang. Berdasarkan hasil wawancara pada siswa yang tingkat kemampuan berpikir kreatif berada pada kategori sangat kurang ini menyatakan tidak tahu caranya mencari besar sudut dari titik pusat ke titik B dan C.

\section{KESIMPULAN}

Berdasarkan hasil penelitian dan pembahasan dapat disimpulkan bahwa kemampuan berpikir kreatif matematik dan self confidence pada siswa SMA masih tergolong rendah. Hal tersebut disebabkan siswa yang memenuhi masing-masing aspek kemampuan berpikir kreatif masih di bawah rata-rata. Kondisi seperti ini disebabkan konsep Trigonometri siswa belum optimal. Siswa terburu-buru dalam mengambil kesimpulan, sehingga dalam penyelesaian masalah kemampuan berpikir kreatif siswa menjadi tidak berkembang untuk memunculkan ide-ide baru, gagasan baru, dan alternative jawaban atau cara lain. Dan masih ditemukan kesalahan lain terutama pada memahami isi soal dan mengidentifikasi unsur-unsur dari informasi yang terdapat pada soal, dan juga siswa kurang memahami materi Trigonometri, terlihat bahwa ketika siswa diminta untuk mengaitkan materi trigonometri ini kepada bentuk permasalahan yang lain, siswa belum mampu untuk menyelesaikannya. Kemudian, berdasarkan hasil penelitian diperoleh bahwa, self confidence berpengaruh kepada peningkatan berpikir kreatif matematik pada siswa. Semakin tinggi self confidence pada siswa, maka rasa ingin tahu siswa akan terdorong dan akan meningkatnya kemampuan berpikir kreatif matematik. Begitupun sebaliknya, semakin rendah self confidence pada siswa, maka rasa ingin tahu siswa kurang terdorong dan ini akan berdampak kepada peningkatan kemampuan berpikir kreatif matematik.

\section{DAFTAR PUSTAKA}

Arifani, H. N., Sunardi, dan Setiawani, S. 2015. "Tingkat Kemampuan Berpikir Kreatif Matematika Siswa SMP Kelas VIII Di SMP Negeri 6 Jember, SMP Al Furqan 1, SMP Negeri 1 Rambipuji, Dan SMP Pgri 1 Rambipuji." Jurnal Kadikma 6: 2. 
Dilla, S. C., Hidayat, W., \& Rohaeti, E. E. (2018). Faktor Gender dan Resiliensi dalam Pencapaian Kemampuan Berpikir Kreatif Matematis Siswa SMA. Journal of Medives, 2(1), 129-136.

Fardah, D. K. 2012. "Analisis Proses Dan Kemampuan Berpikir Kreatif Siswa Dalam Matematika Melalui Tugas Open Ended.” Jurnal Kreano vol 3(2).

Fitriarosah, N. 2016. "Pengembangan Instrumen Berpikir Kreatif Matematis Untuk Siswa SMP.” Prosiding Seminar Nasional Pendidikan Matematika vol 1.

Hendiana, H. Rohaeti, E. dan Sumarmo, U. 2014. HARD SKILLS Dan SOFT SKILLS. Bandung: Refika Aditama.

Hidayat, W. (2011). Meningkatkan Kemampuan Berpikir Kritis dan Kreatif Matematik Siswa Melalui Pembelajaran Kooperatif Think-Talk-Write (TTW) (Doctoral dissertation, Universitas Pendidikan Indonesia).

Hidayat, W. (2012). Meningkatkan Kemampuan Berpikir Kritis dan Kreatif Matematik Siswa SMA Melalui Pembelajaran Kooperatif Think-Talk-Write (TTW). In Seminar Nasional Penelitian, Pendidikan dan Penerapan MIPA.

Maretha, A., ibrahim, I., Dkk. 2014. "Self Confidence Siswa Dalam Menyelesaikan Tudas Dan Implikasinya Terhadap Layanan Bimbingan Dan Konseling.” Jurnal Konselor Vol $3(3)$.

Martyanti, A. 2013. "Membangun Self-Cofidence Siswa Dalam Pembelajaran Matematika Dengan Pendekatan Problem Solving." prosiding.

Purnomo, D.J., Asikin, M., Junaedi, I. 2015. "Tingkat Berpikir Kreatif Pada Geometri Siswa Kelas VII Ditinjau Dari Gaya Kognitif Dalam Setting Problem Based Learning." Jurnal Unnes Journal of Mathematics Education Vol 4(2).

Ruseffendi, E. T. Statistika Dasar Untuk Penelitian Pendidikan Dan Kebudayaan Dirjen Pendidikan Tinggi. Proyek Pembinaan Tenaga Pendidikan Tinggi.

Sumarmo, U., Hidayat, W., Zukarnaen, R., Hamidah, M., \& Sariningsih, R. (2012). Kemampuan dan Disposisi Berpikir Logis, Kritis, dan Kreatif Matematik (Eksperimen terhadap Siswa SMA Menggunakan Pembelajaran Berbasis Masalah dan Strategi Think-Talk-Write). Jurnal Pengajaran MIPA, 17(1), 17-33.

Sumarmo, U., Mulyani, E., \& Hidayat, W. (2018). Mathematical Communication Ability and Self Confidence Experiment with Eleventh Grade Students Using Scientific Approach. JIML-Journal of Innovative Mathematics Learning, 1(1), 19-30.

Tresnawati, T., Hidayat, W., \& Rohaeti, E. E. (2017). Kemampuan Berpikir Kritis Matematis dan Kepercayaan Diri Siswa SMA. Symmetry: Pasundan Journal of Research in Mathematics Learning and Education, 2(2), 39-45. 